This article was downloaded by: [New York University]

On: 29 April 2015, At: 15:46

Publisher: Routledge

Informa Ltd Registered in England and Wales Registered Number: 1072954

Registered office: Mortimer House, 37-41 Mortimer Street, London W1T

3J H, UK

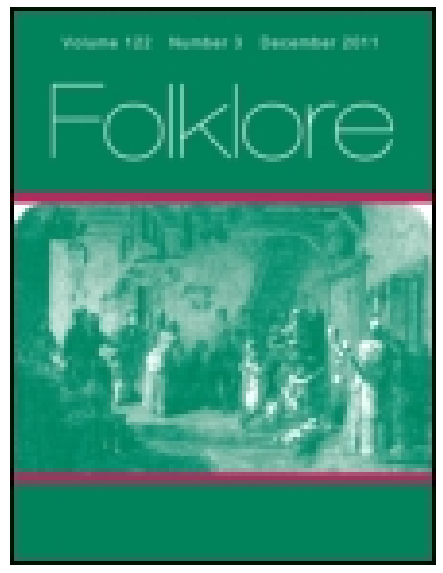

\title{
Folklore
}

Publication details, including instructions for authors and subscription information:

http:// www. tandfonline.com/loi/ rfol20

\section{Customs at Death on the Lower Congo}

J. H. Weeks

Published online: 06 Feb 2012.

To cite this article: J . H. Weeks (1912) Customs at Death on the Lower Congo, Folklore, 23:2, 215-218, DOI: 10.1080/0015587X.1912.9719523

To link to this article: http:// dx. doi. org/ 10.1080/0015587X.1912.9719523

\section{PLEASE SCROLL DOWN FOR ARTICLE}

Taylor \& Francis makes every effort to ensure the accuracy of all the information (the "Content") contained in the publications on our platform. However, Taylor \& Francis, our agents, and our licensors make no representations or warranties whatsoever as to the accuracy, completeness, or suitability for any purpose of the Content. Any opinions and views expressed in this publication are the opinions and views of the authors, and are not the views of or endorsed by Taylor \& Francis. The accuracy of the Content should not be relied upon and should be independently verified with primary sources of information. Taylor and Francis shall not be liable for any losses, actions, claims, proceedings, demands, costs, expenses, damages, and other liabilities whatsoever or howsoever caused arising directly or indirectly in connection with, in relation to or arising out of the use of the Content.

This article may be used for research, teaching, and private study purposes. Any substantial or systematic reproduction, redistribution, reselling, loan, sub-licensing, systematic supply, or distribution in any form to anyone is 
expressly forbidden. Terms $\&$ Conditions of access and use can be found at http://www.tandfonline.com/page/terms-and-conditions 
In concluding this survey of the traditional. beliefs (other than folk-tales) of County Clare, I am quite prepared to learn that I have failed to secure much that is well known to residents in the county. Even my mistakes and omissions, if they lead the people of Clare to abandon their apathy and to correct and supply the deficiencies of my notes, will have helped on the cause of Irish folklore study, and much that is on the point of being forgotten may be rescued for scientific workers on that most important and fascinating subject. ${ }^{87}$

Thos. J. WeSTropp.

"Additional Erratum, vol. xii., p. 54. For Terry Island read Torry Island.

Customs at Death on the Lower Congo.

THE following notes are additions to those already published in Folk-Lore ${ }^{1}$ concerning burial, mourning, and other customs and beliefs connected with death on the Lower Congo.

Burial fees.-The fee for digging a grave is a fowl for each person. If a visitor dies in a town, his people have to pay a pig for the right of burial. If the corpse is taken away, a pig must be paid to the people of every town through which it is carried. This has the effect of reducing the risks of catching infectious diseases, as the bearers, to avoid such heavy fees, will take a body to its native town by wide détours instead of over the usual paths. The body is, however, allowed to pass free if it is that of a man killed by a wild animal, or of a woman dead in childbirth.

Purification.-Those who: dig a grave must; go straight to running water and wash themselves all over. , Those; who, touch a corpse must wash their hands and arms, Those who have dug a grave or touched a corpse cross their outstretched arms until they have washed. : With this sign that they are unclean, no one will want to salute them or to shake hands.

Chiefs' funerals; property put in graves. - When a.chief died in French Congo in November, 1908 , his coffin, made by a native carpenter of my acquaintance, measured, $12 \mathrm{ft}$ by $3 \mathrm{ft} .6 \mathrm{in}$, and

1 Vol., xix., pp. 415-6, 421-3, 428-31 ; vol.' xx., pp. 52, 55-6, 58-61,465, 475 . 
was $4 \mathrm{ft}$. deep. As he had no heirs all his goods and property, except enough to pay his funeral expenses, were heaped upon the body. A native brickmaker and bricklayer had an order for 3000 bricks to build a vault and floor the grave. The flooring is intended to avert the sinking of the body into the earth, which is thought to have happened when the earth sinks on a grave.

Makitu, chief of the district around Wathen, died and was buried in 1898 . His coffin rested on three pieces of ivory cut from a tusk which he had saved for years for this purpose. One loaded gun was buried with him, so that, when he arrived in the "spirit forest," he could shoot the spirit of the ndoki (witch) who had brought him to his death. They intended to bury two women and one man alive in his grave, but this was prevented by missionaries; it is still uncertain, nevertheless, whether one woman, who was missed about the time of the funeral, was not actually buried with the corpse. As regards ivory put in a grave, it is the native belief that only the evuvu, or shell, is left of it. If any person removed the ivory and succeeded in selling it, he would be alleged to be a witch, since he was able to convert the evuru into real ivory. Similarly, if a person took a plate or a bottle from a grave and was able to use it, this would be regarded as an undeniable proof that he was a witch. Such a thief would in the old days have been killed, and his or her blood poured on the grave to appease the robbed and wrathful spirit.

Compensation to family for deaths. - A man living at Nkondo; a village near Wathen, was very ill, near to death in fact, and did not desire to leave his property (trade goods, guns, gunpowder, etc.) to his relatives. So he made up his mind to burn down the house containing the goods. He waited for an opportunity, and one night, when five persons, - three adults and two children,-were sleeping in the house, he locked the door, set fire to the structure, and rolled himself in his blankets to await death. Only one man escaped. The family of the two children demanded, and received, compensation for their death from the suicide's family.

Sacrifices on graves.-In olden times slaves were killed, and their blood poured on the grave of their master. In the early days of the Congo Free State, an officer arrived and stopped for 
the night at a town called $\mathrm{Z}-$, near Kimpese, and saw the funeral of the late chief of the town, at which a native band played. The officer wanted the band's ivory trumpets, and attempted to take them by force. The people resisted, and tied him up. Some desired to kill him and pour his blood over the new grave, but, fortunately for him, others would not agree to this. As a compromise, they shaved off his hair, eyebrows, and beard, and let him go. He never knew how narrowly he had escaped sacrifice on a native chief's grave.

Future life and abode.-The sun was the place of punishment for bad people. When natives want to punish a child they put it out in the strong sun, and men and women were often tied in the scorching sunshine as a penalty for wrong-doing. The moon was supposed to be the place where good people talked (moka) with God. They believed that after death there was a mavambu ma njila, or dividing of the roads, one road leading to the sun, and the other to the moon. The bad people always went the former road, and the good people the latter one. When they see a halo round the sun, they say the mbaji a nkanu, or judgment court, is being held there, and the punishment is being confirmed (sikidiswa). When a circle is seen round the moon, the mbaji a nkanu is being held there, and the reward is being confirmed to the good, so that the family which buries a relative about that time is very happy. ${ }^{2}$ There is a native proverb that indicates that punishment in the sun does not kill :- "The bad are tormented like a locust on burning grass. It wants to die but cannot die ; it wants to be saved, but cannot be saved." This figure of speech is taken from seeing the locusts, when the bush is burning, jumping from stem to stem of the grass in the smoke.

It will be observed that the sun and moon theory as to the places of punishment and reward is opposed to their belief concerning the great spirit town in the forest so fully described in a previous paper. I am inclined to think that the sun and moon theory may be a corruption of the old Roman Catholic teaching on purgatory etc., and that the spirit town in the forest ${ }^{3}$ is the original native belief. Sometimes a curious mixture of both ideas will be found. For example, if there is, as often happens, no halo round either s Vol. xx., p. 59. 'Vol. xx., p. 55 . 
sun or moon for weeks, the persons buried during that period are looked on as neither very bad nor very good, and, therefore, ' to have gone, not to the sun or moon, but to the spirit town in the great forest.

J. H. WeEKS.

\section{Folklore Scraps from Greece and Asia Minor.}

Beetle belief.-In the island of Melos a small black beetle is much feared. It is about half an inch long, and its bite is said to be deadly, killing almost instantaneously. In the course of the excavations of the British School in the spring of IgIr, two were met with, causing on each occasion great excitement. After pickaxes and shovels had done their worst, there remained, unfortunately, so little of the creature that it was impossible to examine.a specimen.

"Forty" as place-name.-In many parts of Greece, (and I believe that the same is true of Turkey), the place-name "Saranda" (Forty) is to be met with. "Forty whats?" you ask, and are told,- ".The name is just Forty." Now, in Greek and Turkish folk-tales $\delta \rho \alpha \dot{x}$ ' (dhraki)-(not 'dragons,' by the way, but 'ogres'; I have.noticed that some European folklorists have been misled by Hahn's translation Drache),-deos, and robbers live in gangs of forty, and the castle of the forty deos, robbers, or $\delta$ páxol, is a very common feature of many of the tales. When travelling through the Cnidian peninsula with Mrr. Dawkins in January, ig1r, we came to a large, round tomb built of squared stones about two and a half hours' journey east of Knidos. On enquiry we learned that the place was called Saranda. It occurred to me that here was a possible explanation of the name. The tomb was the castle of the.forty robbers or devs." The suspicion is partially confirmed by a reference I found subsequently in Traditions populaires de PAsie Mineure, par E. Henry Carnoy et Jean Nicolaides, (Les Littiratures Populaires de toutes les Nations, vol. xxviii., p. 357), where tradition definiteiy states that the "Caves of the Forty" near Judje Su in Cappadocia are so called for the reason which I suggest. is the explanation of the frequent occurrence elsewhere of Saranda as a place name. 